\title{
Tree volume modeling for forest types in the Atlantic Forest: generic and specific models
}

\author{
Vinicius Costa Cysneiros ${ }^{(1)}$, \\ Tatiana Dias Gaui ${ }^{(2-3)}$, \\ Telmo Borges Silveira Filho ${ }^{(4)}$, \\ Allan Libanio Pelissari ${ }^{(1)}$, \\ Sebastião do Amaral Machado ${ }^{(1)}$, \\ Daniel Costa de Carvalho ${ }^{(3)}$, \\ Tom Adnet Moura ${ }^{(4)}$, \\ Hugo Barbosa Amorim ${ }^{(4)}$
}

\begin{abstract}
National Forest Inventories are important primary data sources for large-scale forest resource surveys, in which volume estimates of sampled trees are essential for quantitative analysis. Volume prediction models in natural forests are scarce in Brazil due to legal restrictions for cutting trees, especially in the Atlantic Forest. This study aimed to fit volume models for the main forest types and timber species of the Atlantic Forest in Rio de Janeiro state, considering two hypotheses: (I) generic volume models provide greater generalizability of estimates; however, (II) they may reduce the accuracy of forest typeand species-specific predictions. Four linear models with logarithmic transformation of variables were evaluated to fit volume models for generic and specific datasets, which correspond to the main forest types and timber species. Goodness-of-fit statistics were calculated to compare the accuracy and efficiency of the models, and selected models were validated through leave-oneout cross-validation procedures. The estimates obtained by generic and specific models were compared by non-parametric hypothesis tests. Generic models showed similar predictions to the specific models for forest types and timber species, with similar potential for stem and total volume predictions. Therefore, generic models can be used for Atlantic Forests in Rio de Janeiro state, while specific models are recommended to obtain more detailed local estimates.
\end{abstract}

Keywords: Allometric Models, National Forest Inventory, Non-destructive Methods, Goodness-of-fit, Stem and Total Volume

port the condition of their forest resources (McRoberts et al. 2012, Vidal et al. 2016). In this context, National Forest Inventories are important primary data sources for national assessments and international reports (McRoberts et al. 2012), in which tree volume predictions are required for forest stock estimates (Gschwantner et al. 2019). The predictions obtained by individual tree models are aggregated at plot level, providing estimates for large areas (McRoberts \& Westfall 2016). However, few studies in Brazil have investigated tree volume models at geographic scales (Vibrans et al. 2015).

Due to the destructive peculiarity of data collection (Gimenez et al. 2017, Oliveira et al. 2018), volume prediction models are rare for the Atlantic Forest, where there are legal restrictions to cutting down trees. As the reliability of these estimates depends on the extent and range of available data (Akindele \& LeMay 2006), the need to develop new local volume models is evident (Vibrans et al. 2015). However, for threatened ecosystems such as the Atlantic Forest, only highly fragmented remnants remain due to anthropogenic changes (Ribeiro et al. 2009). In this context, precise assessments of allometric variables are required for adequate conservation and management planning of forest resources on a large-scale.

In addition, most allometric models devel- oped for tropical and subtropical forests have been fitted to estimate only stem volume and do not consider tree crown volume (Segura \& Kanninen 2005, Oliveira et al. 2018). These models exclude an important tree woody component and underestimate wood stocks present in natural forests. Another criticism is related to the model's selection procedures, which are one of the most important sources of uncertainty in quantifying forest stocks (Sileshi 2014). The volume models developed for Brazilian forests have commonly ignored linear regression assumptions, the bias in logarithmic back-transformation, and selection statistical parameters in variable original scales (Vibrans et al. 2015). Therefore, the lack of tree volume models for native forest, associated with statistical fragility of the available models, represents a gap in knowledge about stocks in Brazilian natural forests.

This paper aims to: (1) fit models for stem and total volumes for forest types of the Atlantic Forest: (2) fit models for stem volume for main timber species; and (3) compare the efficiency and accuracy of generic and specific models. For this, two hypotheses were considered: (I) generic volume models can provide a greater ability to generalize estimates, since they cover a larger variability of the allometric relationships; however, (II) due to increased data variability, generic models may result in lower 


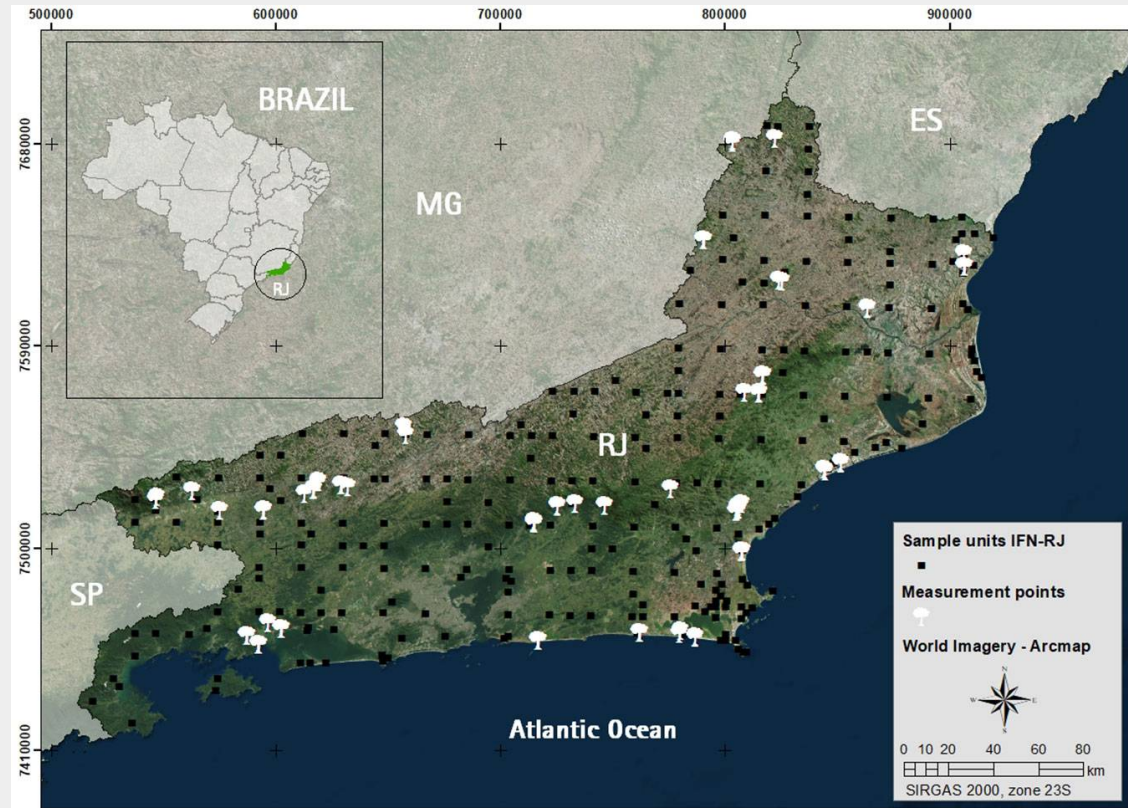

Fig. 1 - Location of NFI-RJ sample plots (black points) and study area for tree measurements (white trees) in Rio de Janeiro State, Southeast of Brazil.

accuracy for estimates by forest type and species.

\section{Material and methods}

\section{Study area and data collection}

The study area covers the three main forest types of the Brazilian Atlantic Forest in Rio de Janeiro state, namely Dense Om brophilous Forest (DOF), Semi-deciduous Seasonal Forest (SSF), and Restinga Forest (RES). These forest types cover $98 \%$ of state territory (Serviço Florestal Brasileiro 2018) at altitudes ranging from 5 to $900 \mathrm{~m}$ a.s.l. Even with geographical proximity, these forest types display floristic and structural differences (Nettesheim et al. 2010, Bergamin et al. 2012) due to the climatic and edaphic gradients that characterize the landscapes (Ribeiro et al. 2018, Sobral et al. 2018). The climate ranges from tropical to humid subtropical, according to the Köppen classification, with Aw-Tropical Dry Winter and Cwa-Subtropical Hot Summer climates predominating. The average annual temperature ranges from $12{ }^{\circ} \mathrm{C}$ to 24 ${ }^{\circ} \mathrm{C}$, with total annual precipitation between 1000 to $2200 \mathrm{~mm}$ (Alvares et al. 2013).

For tree measurements, 28 forest remnants (Fig. 1) were selected based on the sample allocated in the National Forest Inventory (NFI-RJ), including 18 Conservation Units and 10 private areas. Three-level samples were used for selecting the trees. The first level included the main forest types of the state territory (SSF, DOF, and RES). The second level regards the main species in abundance, based on the forest structure analysis of the state (NFI-RJ). The third level followed the diameter distribution in forest types.

At these locations, a total of 583 tree stems and 172 tree crowns were used for sampling. The sample included 85 species

Tab. 1 - Descriptive statistics and sample sufficiency of the dataset by forest types. (DOF): Dense Ombrophilous Forest; (RES): Restinga Forest; (SSF): Semi-deciduous Seasonal Forest; (dev): deviations; $(n)$ : minimum sample size determined considering error of $10 \%$ and probability level of $95 \%$.

\begin{tabular}{|c|c|c|c|c|c|c|c|c|c|}
\hline \multirow{2}{*}{ Data } & \multirow{2}{*}{ Types } & \multicolumn{2}{|c|}{$\mathrm{dbh}(\mathrm{cm})$} & \multicolumn{2}{|c|}{$h(m)$} & \multicolumn{2}{|c|}{$v\left(m^{3}\right)$} & \multicolumn{2}{|c|}{$\begin{array}{l}\text { Sampling } \\
\text { sufficiency }\end{array}$} \\
\hline & & mean & dev & mean & dev & mean & dev & $\mathrm{n}$ & $\begin{array}{l}\text { sampled } \\
\text { trees }\end{array}$ \\
\hline \multirow{4}{*}{$\stackrel{E}{ \pm}$} & Generic & 25.04 & 7.16 & 9.68 & 2.56 & 0.41 & 0.27 & 45 & 583 \\
\hline & DOF & 26.18 & 8.17 & 10.11 & 2.44 & 0.46 & 0.31 & 46 & 254 \\
\hline & RES & 21.3 & 4.89 & 7.23 & 1.61 & 0.23 & 0.12 & 18 & 110 \\
\hline & SSF & 25.55 & 6.59 & 10.41 & 2.63 & 0.45 & 0.28 & 49 & 209 \\
\hline \multirow{4}{*}{ 葛 } & Generic & 23.78 & 5.2 & 16.62 & 3.44 & 0.48 & 0.27 & 41 & 172 \\
\hline & DOF & 25.04 & 5.5 & 17.99 & 3.54 & 0.54 & 0.28 & 43 & 78 \\
\hline & RES & 19.47 & 3.13 & 13.1 & 2.1 & 0.26 & 0.12 & 17 & 37 \\
\hline & SSF & 24.86 & 4.93 & 17.03 & 3 & 0.55 & 0.29 & 44 & 57 \\
\hline
\end{tabular}

of 29 botanical families (Tab. S1 in Supplementary material) that were classified according to APG IV (The Angiosperm Phylogeny Group 2016). Botanical material was collected from all sample units for taxonomical identification, according to Jara et al. (2015). Botanical vouchers were deposited in the RBR herbarium of the Department of Botany of the Federal Rural University of Rio de Janeiro. Species were identified using RBR herbarium reference collections and also by consulting with specialists. Spellings, synonyms, and taxonomic issues were checked and standardized using the Tropicos database (Boyle et al. 2013).

A non-destructive method was used to climb trees and obtain their volume without cutting them down. In this method, diameter measurements along stem and crown were performed on standing trees with climbing techniques and equipment (Fig. S1 in Supplementary material), which do not cause physical damage to the trees (Laman 1995). This method is an alternative for obtaining tree volume data (Gimenez et al. 2017), especially in the Atlantic Forest, where there are legal restrictions for cutting down trees. Remote Sensing Tools as Terrestrial Laser Scanning (TLS) are other alternatives to destructive techniques for assessing single-tree properties (Stoval et al. 2018). However, the TLS use at a large scale was unfeasible due to the highly sloping landscapes in study area.

For stem volume data $\left(\mathrm{v}_{\text {stem }}\right), 583$ trees were measured: 264 in DOF, 209 in SSF, and 110 in RES (Tab. 1). The diameter at breast height $(\mathrm{dbh})$, stem height $\left(\mathrm{h}_{\text {stem }}\right)$, and diameters $\left(\mathrm{d}_{\mathrm{i}}\right)$ at heights of $0.3,0.5,1$, 1.3 , and $2 \mathrm{~m}$ as well as each one meter until the crown base were measured. The stem height was assigned as the last measurement at the crown base, according to $\mathrm{Vi}$ brans et al. (2015). Section volumes were calculated by the Smalian's method (Avery \& Burkhart 2015), in which the sum of all sections correspond to the stem volume.

Tree total volume $\left(v_{\text {total }}\right)$ was obtained with the sum of stem and crown volumes $\left(\mathrm{v}_{\text {crown }}\right)$. For this, 172 crowns of the sampled trees were measured: 78 in DOF, 57 in SSF, and 37 in RES. Branches were sectioned at $1 \mathrm{~m}$ or in irregular sections (length $<1 \mathrm{~m}$ ) and individually measured to the threshold diameter of $5 \mathrm{~cm}$. Branch volume was calculated by the Smalian's method, in which the sum of all branches' volume corresponds to the crown volume. Total height $\left(\mathrm{h}_{\text {total }}\right)$ was measured with a ECII-R ${ }^{\circledR}$ precision clinometer (Haglöf, Sweden).

Exploratory data analysis was carried out to identify the dispersion and distribution of the variables used for modeling. Scatterplots of tree volume vs. dbh were used to explore the data trends, and box plots was applied to verified the data distributions. This analysis was performed for all data sets that corresponded to generic data and each subset by forest type and timber species. Different trends and patterns were 
evidenced for the datasets, as the heteroscedasticity and outliers presence.

\section{Data analysis}

Based on exploratory analysis, four traditional volume models (Tab. 2) were fitted in their linear form by logarithmic transformation to predict stem and total volumes. These models were fitted for generic and specific datasets, corresponding to the three main forest types (SSF, DOF, and RES) and four timber species with management potential in the Atlantic Forest, according to Nascimento et al. (2017) and Oliveira et al. (2018): Apuleia leiocarpa (Vogel) J. F. Macbr., Astronium graveolens Jacq., Miconia cinnamomifolia (DC.) Naudin, and Pseudopiptadenia contorta (DC.) G. P. Lewis \& M. P. Lima. Only models to predicted stem volume were fitted due to the limited number of sample units for these species (Tab. S1 in Supplementary material).

Considering that back-transformation of logarithmic predictions to the original scale produces a bias, a correction term must be added to compensate for the scale change (Vibrans et al. 2015). This correction term is expressed by the exponential of residual variance divided by two. According to these authors, low values of the correction term provide low influence on the final result. Since all terms were $<0.05$, they can be considered negligible. Therefore, the correction term was not applied in the present study.

Lower root mean square error (RMSE\%), higher values of adjusted coefficient of determination (adj- $\mathrm{R}^{2}$ ) and Akaike information criterion (AIC) were the statistical criteria used to select the best models, by means of the formulation presented by Bennett et al. (2013). These statistics were recalculated at their original scales due to the logarithmic transformation of the variables. The $F$ test for lack of fit was conducted to verify that linear models present a good fit for the databases. This hypothesis test considered $\alpha=0.05$.

Residual analysis was considered decisive for selecting the best models (Bennett et al. 2013), especially to verify the linear regression assumptions. The normality of residuals was verified by the KolmogorovSmirnov's (KS) test (Razali \& Wah 2011) using the package "nortest" in R (Gross \& Ligges 2015), while the Breusch-Pagan's (BP) test was used for homoscedasticity assessment (Breusch \& Pagan 1979). All these hypothesis tests considered $\alpha=0.01$. Scatterplots of studentized residuals by estimated values and quantile-quantile plots at $95 \%$ probability were evaluated for the selected models.

The variance inflation factor (VIF) was calculated for two-predictor models, aiming to identify possible multicollinearities of predictor variables (Sileshi 2014). Collinear variables were removed considering a VIF threshold value equal to 5 . The significance of regression coefficients $\left(\beta_{i}\right)$ was evalu-

Tab. 2 - Models for tree volume predictions in the Atlantic Forest of Rio de Janeiro state, Brazil. $(\mathrm{v})$ : tree volume $\left(\mathrm{m}^{3}\right) ;(\mathrm{dbh})$ : diameter measured at breast height $(\mathrm{cm})$; $(h)$ : height $(\mathrm{m}) ;\left(\varepsilon_{\mathrm{i}}\right)$ : random error.

\begin{tabular}{cllc}
\hline Model & Author & Volume model & $\begin{array}{c}\text { Independent } \\
\text { variables }\end{array}$ \\
\hline 1 & Kopezky-Gehrhardt & $\ln (\mathrm{v})=\beta_{0}+\beta_{1^{*}} \ln \left(\mathrm{dbh}^{2}\right)+\varepsilon_{\mathrm{i}}$ & Single-predictor \\
\hline 2 & Brenac & $\ln (\mathrm{v})=\beta_{0}+\beta_{1} \cdot \ln (\mathrm{dbh})+\beta_{2} \cdot(1 / \mathrm{dbh})+\varepsilon_{\mathrm{i}}$ & \\
\hline 3 & Modified Spurr & $\ln (\mathrm{v})=\beta_{0}+\beta_{1} \cdot \ln \left(\mathrm{dbh}^{2} \cdot \mathrm{h}\right)+\varepsilon_{\mathrm{i}}$ & Two-predictors \\
\hline 4 & Schumacher-Hall & $\ln (\mathrm{v})=\beta_{0}+\beta_{1} \cdot \ln (\mathrm{dbh})+\beta_{2} \cdot \ln (\mathrm{h})+\varepsilon_{\mathrm{i}}$ & \\
\hline
\end{tabular}

ated by the $t$-test $(\alpha=0.01)$. The influence of outliers was analyzed in the selected models through graphical analysis, considering the studentized residuals, leverage values, and Cooks' Distance weights for each observation using the "car" $\mathrm{R}$ package (Fox \& Weisberg 2019).

Leave-one-out cross-validation was applied to validate the selected models (Mauya et al. 2014, Oliveira et al. 2018) using the "caret" R package (Kuhn et al. 2018). In this process, one observation ( $n$ ) at a time was removed from the database, and the model was refitted $n$ times. The root mean square error (RMSE\%) and adjusted coefficient of determination (adj- $R^{2}$ ) obtained from cross-validation were used to validate the models (Sileshi 2014). The predicted volumes were graphically represented in relation to the observed volumes on the original scale (Jara et al. 2015), aiming to identify possible bias in predictions.

\section{Model comparisons}

For testing the hypotheses about predictions obtained by generic and specific models, the selected models were compared in two situations: (i) generic vs. specific models by forest type to estimate the stem and total volumes; and (ii) generic vs. specific models by timber species to estimate stem volume. The non-parametric chi-squared test $\left(X^{2}\right)$ and the Wilcoxon test for paired data (V) were applied to verify significant similarity among the generic and specific predictions. Kruskal-Wallis' non-parametric test $(\mathrm{H})$ was used to compare simultaneously the predictions of generic and specific models with observed values. All these hypothesis tests used $a=0.01$. Willmott's Agreement Index (dw) was calculated (Willmott 1981) to verify agreement among the values estimated by the models, with the use of "hydroGOF" R package (Zambrano-Bigiarini 2017). The dw index ranges from 0 to 1 , where the maximum value indicates perfect agreement between pairs of values. Additionally, variations in RMSE\% and adj- $R^{2}$ were calculated for models accuracy comparison.

\section{Results}

While allometric relationships showed similarity between SSF and DOF forest types (Fig. 2), a distinct pattern was observed in RES. In this forest type, the volumes are concentrated in the smallest diameter classes, and the allometric relation-
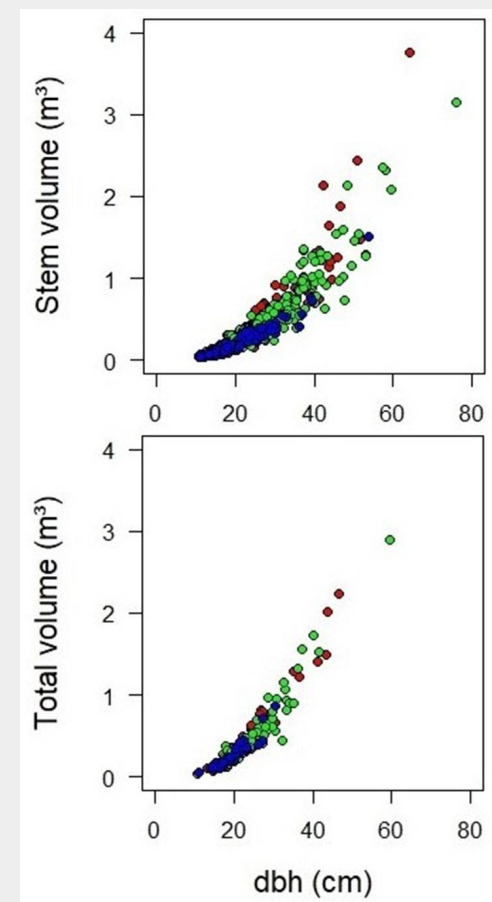
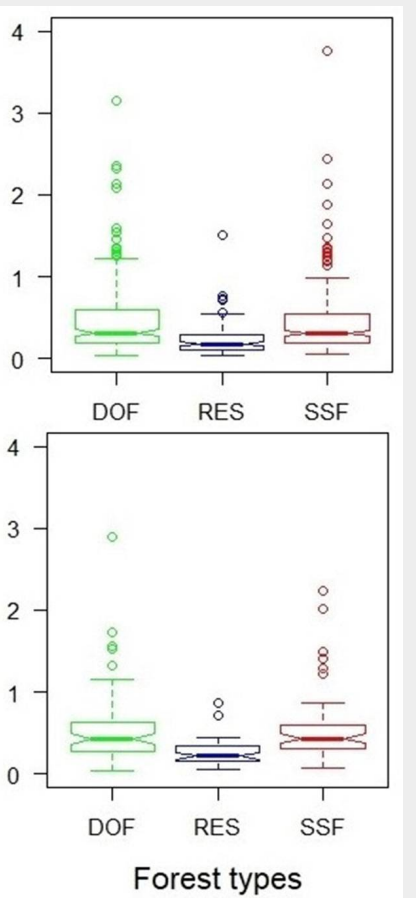

Fig. 2 - Tree volume-diameter relationships in forest types of the Brazilian Atlantic Forest, showing Dense Ombrophilous Forest (DOF, green), Restinga Forest (RES, blue), and Semideciduous Seasonal Forest (SSF, red). 
Tab. 3 - Statistical parameters of fitted models to estimate stem and total volumes in the Brazilian Atlantic Forest. The p-value corresponds to lack-of-fit test performed only on the best model selected for each dataset. (SE): standard error of estimated parameters; $\left(^{*}\right): p<0.05 ;(* *): p<0.01 ;(n s):$ non-significant.

\begin{tabular}{|c|c|c|c|c|c|c|c|c|c|c|c|c|}
\hline Volume & Data & Model & $\boldsymbol{\beta}_{0}$ & $\mathrm{SE}_{\beta 0}$ & $\boldsymbol{\beta}_{1}$ & $\mathrm{SE}_{\beta 1}$ & $\boldsymbol{\beta}_{2}$ & $\mathrm{SE}_{\beta 2}$ & RMSE\% & $\operatorname{adj}-R^{2}$ & AIC & $p$ \\
\hline \multirow[t]{16}{*}{ Stem } & \multirow[t]{4}{*}{ Generic } & 1 & $-8.375^{* *}$ & 0.098 & $1.131^{* *}$ & 0.015 & - & - & 36.39 & 0.865 & -550 & - \\
\hline & & 2 & $-7.198^{* *}$ & 0.601 & $1.982^{* *}$ & 0.144 & $-6.568^{*}$ & 3.308 & 35.32 & 0.872 & -583 & - \\
\hline & & 3 & $-9.359^{* *}$ & 0.052 & $0.952^{* *}$ & 0.006 & - & - & 17.05 & 0.971 & -1433 & - \\
\hline & & 4 & $-9.341^{* *}$ & 0.041 & $2.053^{* *}$ & 0.012 & $0.734^{* *}$ & 0.012 & 14.77 & 0.978 & -1599 & 0.25 \\
\hline & \multirow[t]{4}{*}{ DOF } & 1 & $-8.070^{* *}$ & 0.139 & $1.087^{* *}$ & 0.022 & - & - & 32.84 & 0.876 & -238 & - \\
\hline & & 2 & $-5.934^{* *}$ & 0.841 & $1.672^{* *}$ & 0.202 & $-12.06^{*}$ & 4.684 & 30.54 & 0.893 & -275 & - \\
\hline & & 3 & $-9.458^{* *}$ & 0.078 & $0.963^{* *}$ & 0.009 & - & - & 15.99 & 0.971 & -618 & - \\
\hline & & 4 & $-9.329^{* *}$ & 0.067 & $2.033^{* *}$ & 0.018 & $0.756^{* *}$ & 0.021 & 14.37 & 0.976 & -673 & 0.43 \\
\hline & \multirow[t]{4}{*}{ RES } & 1 & $-8.360^{* *}$ & 0.217 & $1.101^{* *}$ & 0.036 & - & - & 21.29 & 0.934 & -348 & - \\
\hline & & 2 & $-7.824^{* *}$ & 1.413 & $2.071^{* *}$ & 0.35 & $-2.726^{\mathrm{ns}}$ & 7.105 & 20.85 & 0.937 & -350 & - \\
\hline & & 3 & $-9.454^{* *}$ & 0.113 & $0.971^{* *}$ & 0.014 & - & - & 10.67 & 0.984 & -500 & - \\
\hline & & 4 & $-9.414^{* *}$ & 0.082 & $2.077^{* *}$ & 0.024 & $0.739^{* *}$ & 0.025 & 9.24 & 0.988 & -529 & 0.87 \\
\hline & \multirow[t]{4}{*}{ SSF } & 1 & $-8.416^{* *}$ & 0.168 & $1.144^{* *}$ & 0.026 & - & - & 34.42 & 0.873 & -184 & - \\
\hline & & 2 & $-8.326^{* *}$ & 1.053 & $2.267^{* *}$ & 0.251 & $-0.514^{\mathrm{ns}}$ & 5.928 & 34.48 & 0.872 & -182 & - \\
\hline & & 3 & $-9.418^{* *}$ & 0.095 & $0.957^{* *}$ & 0.011 & - & - & 18.39 & 0.964 & -446 & - \\
\hline & & 4 & $-9.402^{* *}$ & 0.073 & $2.082^{* *}$ & 0.022 & $0.718^{* *}$ & 0.021 & 14.06 & 0.979 & -557 & 0.16 \\
\hline \multirow[t]{16}{*}{ Total } & \multirow[t]{4}{*}{ Generic } & 1 & $-8.988^{* *}$ & 0.179 & $1.277^{* *}$ & 0.028 & - & - & 31.29 & 0.860 & -155 & - \\
\hline & & 2 & $-6.074^{* *}$ & 1.11 & $1.856^{* *}$ & 0.268 & $-16.013^{* *}$ & 6.024 & 22.57 & 0.927 & -266 & - \\
\hline & & 3 & $-9.381^{* *}$ & 0.149 & $0.928^{* *}$ & 0.016 & - & - & 20.18 & 0.942 & -306 & 0.82 \\
\hline & & 4 & $-9.370^{* *}$ & 0.146 & $2.038^{* *}$ & 0.067 & $0.720^{* *}$ & 0.069 & 21.54 & 0.933 & -282 & - \\
\hline & \multirow[t]{4}{*}{ DOF } & 1 & $-8.490^{* *}$ & 0.278 & $1.200^{*}$ & 0.043 & - & - & 28.29 & 0.872 & -66 & - \\
\hline & & 2 & $-5.968^{* *}$ & 1.618 & $1.799^{*}$ & 0.389 & $-14.163^{\mathrm{ns}}$ & 8.955 & 22.18 & 0.921 & -102 & - \\
\hline & & 3 & $-9.228^{* *}$ & 0.233 & $0.908^{*}$ & 0.025 & - & - & 18.53 & 0.945 & -132 & 0.63 \\
\hline & & 4 & $-9.159^{* *}$ & 0.229 & $1.979^{*}$ & 0.086 & $0.703^{*}$ & 0.093 & 19.39 & 0.939 & -123 & - \\
\hline & \multirow[t]{4}{*}{ RES } & 1 & $-9.493^{* *}$ & 0.426 & $1.354^{* *}$ & 0.072 & - & - & 20.95 & 0.887 & -104 & - \\
\hline & & 2 & $-11.23^{* *}$ & 3.643 & $3.149^{* *}$ & 0.929 & $8.184^{\mathrm{ns}}$ & 17.03 & 21.04 & 0.882 & -102 & - \\
\hline & & 3 & $-9.848^{* *}$ & 0.344 & $0.987^{* *}$ & 0.041 & - & - & 16.97 & 0.926 & -119 & 0.59 \\
\hline & & 4 & $-9.849^{* *}$ & 0.346 & $2.089^{* *}$ & 0.175 & $0.853^{* *}$ & 0.183 & 16.99 & 0.924 & -118 & - \\
\hline & \multirow[t]{4}{*}{ SSF } & 1 & $-9.130^{* *}$ & 0.329 & $1.304^{* *}$ & 0.052 & - & - & 22.98 & 0.911 & -68 & - \\
\hline & & 2 & $-3.956^{\mathrm{ns}}$ & 2.186 & $1.387^{*}$ & 0.521 & $-30.05^{*}$ & 12.57 & 17.87 & 0.945 & -95 & - \\
\hline & & 3 & $-9.671^{* *}$ & 0.291 & $0.963^{* *}$ & 0.032 & - & - & 19.17 & 0.938 & -89 & 0.31 \\
\hline & & 4 & $-9.621^{* *}$ & 0.294 & $2.073^{* *}$ & 0.139 & $0.780^{* *}$ & 0.158 & 19.75 & 0.933 & -83 & - \\
\hline
\end{tabular}

Tab. 4 - Statistical parameters of fitted models to estimate stem volume of timber species in the Brazilian Atlantic Forest. The $\mathrm{p}$ value corresponds to lack-of-fit test performed only on the best model selected for each timber species. (SE): standard error of estimated parameters; $(*): p<0.05 ;(* *): p<0.01 ;(n s)$ : non-significant.

\begin{tabular}{|c|c|c|c|c|c|c|c|c|c|c|c|}
\hline Species & Model & $\boldsymbol{\beta}_{0}$ & $S E_{\beta 0}$ & $\boldsymbol{\beta}_{1}$ & $\mathrm{SE}_{\beta 1}$ & $\boldsymbol{\beta}_{2}$ & $\mathrm{SE}_{\mathrm{B} 2}$ & RMSE\% & adj-R ${ }^{2}$ & AIC & $\mathrm{p}$ \\
\hline \multirow{4}{*}{$\begin{array}{l}\text { Apuleia } \\
\text { leiocarpa }\end{array}$} & 1 & $-7.661^{* *}$ & 0.278 & $1.032^{* *}$ & 0.042 & - & - & 28.52 & 0.909 & -45 & - \\
\hline & 2 & $-4.642^{* *}$ & 1.519 & $1.363^{* *}$ & 0.356 & $-18.053^{*}$ & 8.938 & 25.91 & 0.923 & -53 & - \\
\hline & 3 & $-9.551^{* *}$ & 0.192 & $0.976^{* *}$ & 0.022 & - & - & 9.25 & 0.990 & -160 & 0.92 \\
\hline & 4 & $-9.231^{* *}$ & 0.173 & $2.026^{* *}$ & 0.039 & $0.732^{* *}$ & 0.054 & 12.16 & 0.983 & -130 & - \\
\hline \multirow{4}{*}{$\begin{array}{l}\text { Astronium } \\
\text { graveolens }\end{array}$} & 1 & $-8.452^{* *}$ & 0.444 & $1.137^{* *}$ & 0.072 & - & - & 38.51 & 0.758 & -76 & - \\
\hline & 2 & $-8.332^{* *}$ & 3.507 & $2.244^{* *}$ & 0.862 & $-0.623^{\text {ns }}$ & 18.06 & 38.49 & 0.753 & -74 & - \\
\hline & 3 & $-9.255^{* *}$ & 0.206 & $0.931^{* *}$ & 0.025 & - & - & 15.62 & 0.960 & -172 & - \\
\hline & 4 & $-9.529^{* *}$ & 0.125 & $2.115^{* *}$ & 0.038 & $0.706^{* *}$ & 0.027 & 7.89 & 0.990 & -242 & 0.63 \\
\hline \multirow{4}{*}{$\begin{array}{l}\text { Miconia } \\
\text { cinnamomifolia }\end{array}$} & 1 & $-8.002^{* *}$ & 0.306 & $1.094^{* *}$ & 0.047 & - & - & 33.45 & 0.777 & -36 & - \\
\hline & 2 & $-6.524^{* *}$ & 2.040 & $1.833^{* *}$ & 0.494 & $-7.962^{\text {ns }}$ & 10.86 & 34.14 & 0.763 & -32 & - \\
\hline & 3 & $-9.322^{* *}$ & 0.161 & $0.951^{* *}$ & 0.018 & - & - & 10.08 & 0.980 & -156 & 0.49 \\
\hline & 4 & $-9.201^{* *}$ & 0.147 & $1.993^{* *}$ & 0.041 & $0.776^{* *}$ & 0.050 & 10.76 & 0.976 & -147 & - \\
\hline \multirow{4}{*}{$\begin{array}{l}\text { Pseudopitadenia } \\
\text { contorta }\end{array}$} & 1 & $-8.374^{* *}$ & 0.270 & $1.131^{* *}$ & 0.043 & - & - & 35.74 & 0.888 & -39 & - \\
\hline & 2 & $-9.280^{* *}$ & 1.795 & $2.475^{* *}$ & 0.425 & $5.126^{\mathrm{ns}}$ & 10.05 & 36.29 & 0.882 & -36 & - \\
\hline & 3 & $-9.124^{* *}$ & 0.135 & $0.928^{* *}$ & 0.016 & - & - & 18.05 & 0.971 & -113 & - \\
\hline & 4 & $-9.096^{* *}$ & 0.099 & $2.004^{* *}$ & 0.032 & $0.703^{* *}$ & 0.035 & 12.70 & 0.986 & -149 & 0.37 \\
\hline
\end{tabular}


Fig. 3 - Scatterplots of studentized residuals and observed vs. predicted tree volumes (using cross-validation) for best-fitted stem volume models in the forest types (model 4): (A) generic data, (B) SSF, (C) DOF, and (D) RES.
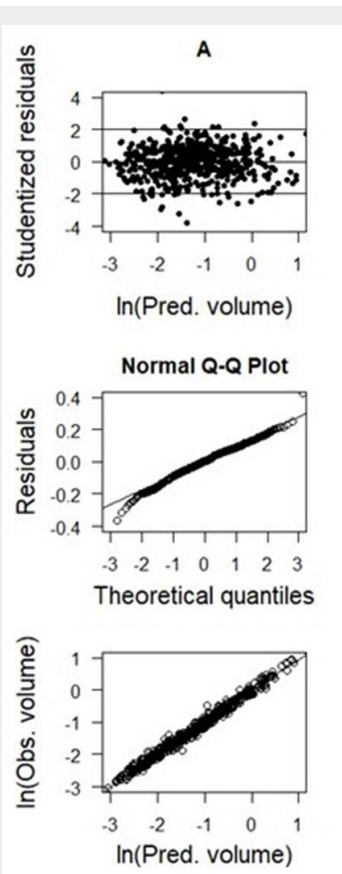

B
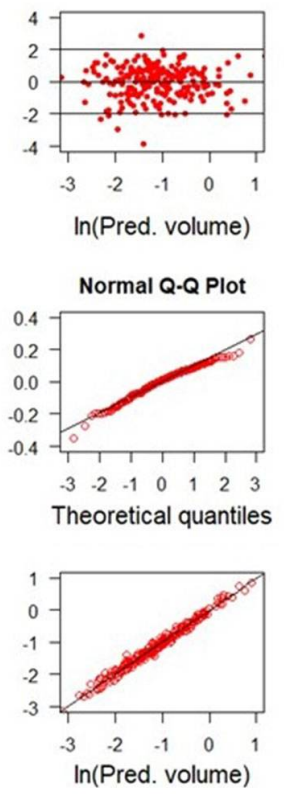

C

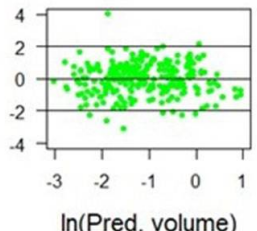

In(Pred. volume)
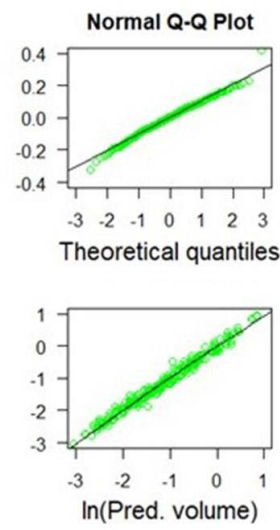

D
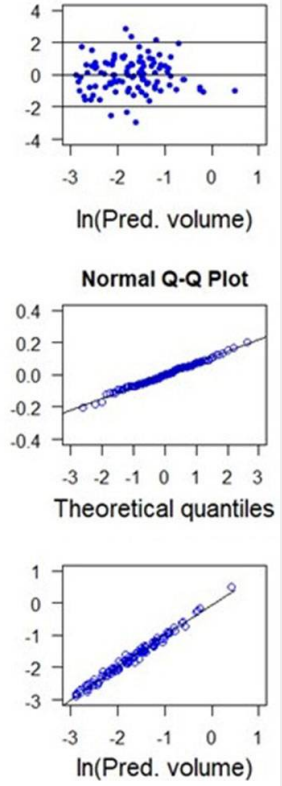

ship was more uniform and possessed less variability. The correlation with predictor variables for total volume was higher ( $\mathrm{dbh}$ $\left.=0.92-0.96 ; h_{\text {total }}=0.68-0.82\right)$ than that for stem volume $\left(\mathrm{dbh}=0.88-0.93 ; \mathrm{h}_{\text {stem }}=0.33^{-}\right.$ 0.50). After logarithmic transformation, the correlation between predictor and response variables increased by $7 \%$ for stem volume and by $8 \%$ for total volume. In this sense, the distribution of allometric variables had become linear, and the presence of outliers was reduced. These results supported the decision to use linear models with logarithmic variables for all volume predictions.

For timber species (Fig. S2 in Supplementary material), stem volume showed similarity between Apuleia leiocarpa and Mico- nia cinnamomifolia; while Astronium graveolens was more similar to Pseudopiptadenia contorta. Predictor variables showed moderate to high correlation in natural scale $\left(d b h=0.83-0.93 ; h_{\text {stem }}=0.16-0.69\right)$ with the response variable $\left(v_{\text {stem }}\right)$. In relation to allometric relationships, heteroscedasticity was detected for P. contorta due to high variability of the largest trees.

Tab. 3 shows the fitting results and statistical criteria used to select the best models. The residuals of selected models presented normality (KS test) and homoscedasticity (BP test). The tests indicated that linear regression assumptions were satisfied, not rejecting any of the null hypotheses ( $p$ > 0.01 ). The selected models did not show lack of fit according to the $\mathrm{F}$ test. Model 4 presented the best fit (lowest AIC) for stem volume prediction, while model 3 showed the best performance for total volume. These models allowed more accurate predictions (lower RMSE) and high explications of observed data (higher adj- $\mathrm{R}^{2}$ ), with significant regression coefficients $(p \leq$ 0.01).

In general, the two-predictor models (3 and 4) presented the best fit compared to the single predictor models ( 1 and 2 ). In this sense, the models calibrated for stem volume had the best predictions (higher adj- $R^{2}$, lower AIC and RMSE) than the ones adjusted for total volume. Although model 1 presented higher prediction errors, it showed significant regression coefficients and satisfied the regression assumptions.
Fig. 4 - Scatterplots of studentized residuals and observed vs. predicted tree volumes (using cross-validation) for best-fitted total volume models in the forest types (model 3): (A) generic data; (B) SSF; (C) DOF; and (D) RES.
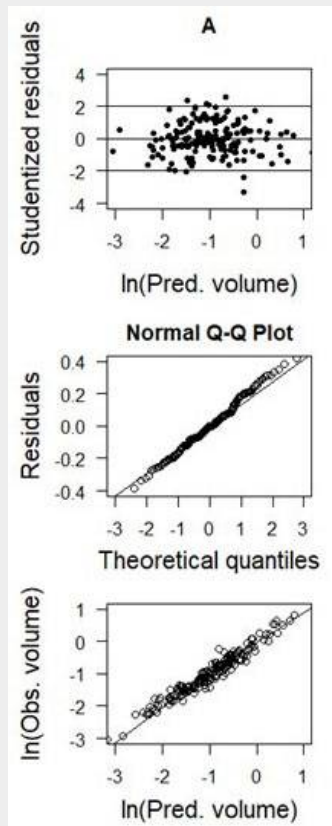

B

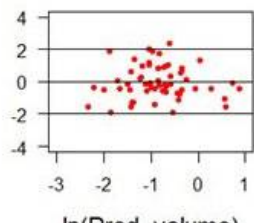

In(Pred. volume)
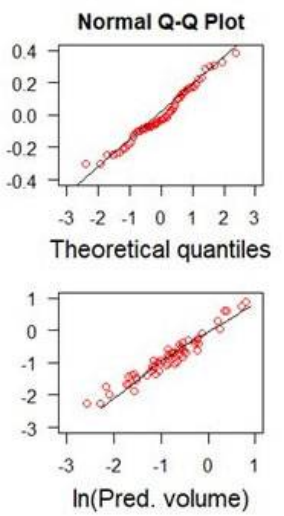

c

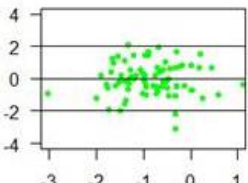

In(Pred. volume)
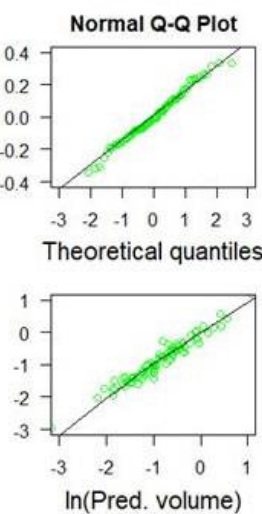

D

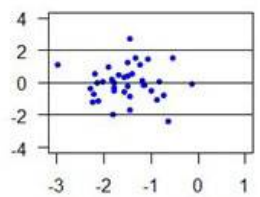

In(Pred. volume)

Normal Q-Q Plot
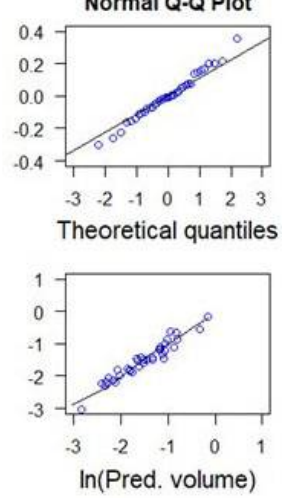

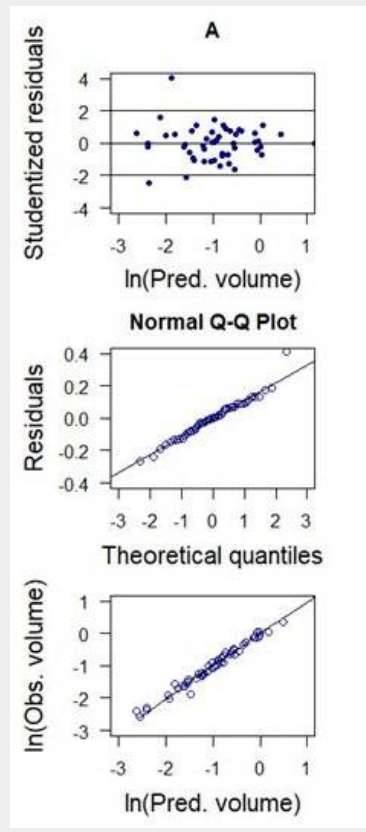

B
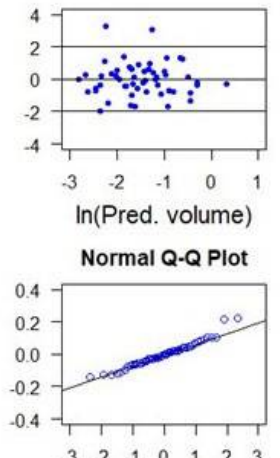

Theoretical quantiles

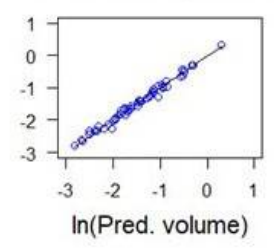

c
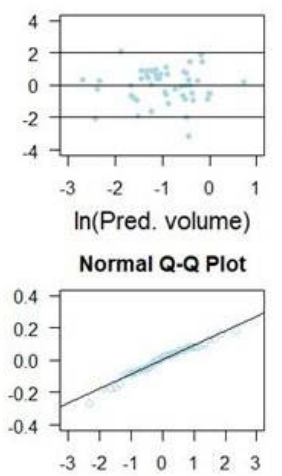

Theoretical quantiles

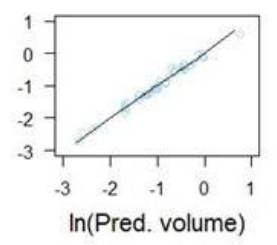

D
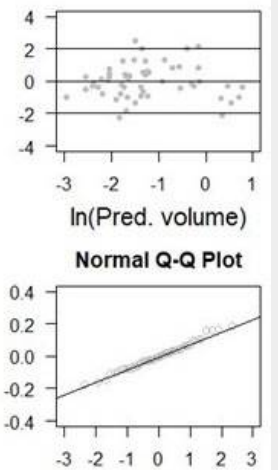

Theoretical quantiles

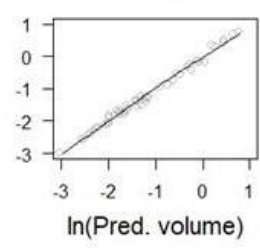

Fig. 5 - Scatterplots of studentized residuals and observed vs. predicted tree volumes (using cross-validation) of best-fitted stem volume models for timber species. (A): model 3 for Apuleia leiocarpa; (B): model 4 for Astronium graveolens; (C): model 3 for Miconia cinnamomifolia; (D): model 4 for Pseudopiptadenia contorta.
Model 2 was the only one that presented regression coefficients with low significance or non-significance as well as multicollinearity, with variance inflation values (VIF) greater than 5. Based on these criteria, model 2 was excluded from the analysis.

Tab. 4 shows the fitting results and respective statistical criteria used to select the best volume models for specific timber species. Model 3 was the best fitting for $A$. leiocarpa and $M$. cinnamomifolia; while model 4 was the most suitable for $A$. graveolens and $P$. contorta predictions. Residual analysis indicated that the residual normality (KS test) and homoscedasticity (BP test) were not rejected $(p>0.01)$. As observed for forest types, two-predictor models 3 and 4 provided more accurate estimates than single predictor models. The inclusion of height resulted in a four times lower er-

Tab. 5 - Chi-squared $\left(\chi^{2}\right)$, Wilcoxon (V), Kruskal-Wallis (H), and Willmott's Agreement Index (dw) statistics and differences between root mean square error in percentage $(\triangle \mathrm{RMSE} \%)$ and adjusted determination coefficient $\left(\Delta \mathrm{adj}-\mathrm{R}^{2}\right)$ by generic and specific models to estimate stem and total volumes in the Brazilian Atlantic Forest. (ns): nonsignificant.

\begin{tabular}{|c|c|c|c|c|c|c|c|}
\hline Volume & Test & $\chi^{2}$ & V & $\mathrm{H}$ & $d w$ & $\triangle \mathrm{RMSE} \%$ & $\Delta \mathrm{adj}-\mathrm{R}^{2}$ \\
\hline \multirow[t]{3}{*}{ Stem } & $\mathrm{GEN} \times \mathrm{DOF}$ & $0.0048^{\text {ns }}$ & $34846^{\text {ns }}$ & $0.0123^{\mathrm{ns}}$ & 0.9999 & 0.560 & 0.0001 \\
\hline & GEN $\times$ RES & $0.0009^{\text {ns }}$ & $5955^{\mathrm{ns}}$ & $0.0455^{\mathrm{ns}}$ & 0.9997 & -1.044 & 0.0001 \\
\hline & $\mathrm{GEN} \times \mathrm{SSF}$ & $0.0043^{\text {ns }}$ & $21945^{\text {ns }}$ & $0.0085^{\text {ns }}$ & 0.9999 & 0.401 & 0.0001 \\
\hline \multirow[t]{3}{*}{ Total } & $\mathrm{GEN} \times \mathrm{DOF}$ & $0.0054^{\text {ns }}$ & $3168^{\text {ns }}$ & $0.1687^{\text {ns }}$ & 0.9978 & 2.443 & -0.0004 \\
\hline & GEN $\times$ RES & $0.0053^{\text {ns }}$ & $661^{\mathrm{ns}}$ & $0.0598^{\text {ns }}$ & 0.9953 & 1.786 & -0.0009 \\
\hline & GEN $\times$ SSF & $0.0111^{\text {ns }}$ & $1562^{\text {ns }}$ & $0.2506^{\text {ns }}$ & 0.9968 & -1.452 & 0.0003 \\
\hline \multirow[t]{4}{*}{ Stem } & $\mathrm{GEN} \times \mathrm{APU}$ & $0.0693^{\text {ns }}$ & $1270^{\text {ns }}$ & $0.0517^{\mathrm{ns}}$ & 0.9969 & 3.378 & -0.0007 \\
\hline & $\mathrm{GEN} \times \mathrm{AST}$ & $0.0028^{\text {ns }}$ & $1486^{\text {ns }}$ & $0.3380^{\text {ns }}$ & 0.9984 & 2.967 & -0.0005 \\
\hline & $\mathrm{GEN} \times \mathrm{MIC}$ & $0.0438^{\text {ns }}$ & $1193^{\text {ns }}$ & $0.2289^{\text {ns }}$ & 0.9946 & 2.878 & -0.0013 \\
\hline & GEN $\times$ PSE & $0.0087^{\mathrm{ns}}$ & $1415^{\mathrm{ns}}$ & $0.0888^{\mathrm{ns}}$ & 0.9997 & 2.877 & -0.0007 \\
\hline
\end{tabular}

iocarpa (Fig. 5A). Outliers were observed for A. leiocarpa (Fig. 5A) and A. graveolens (Fig. 5B) at the upper extremes of their distributions.

All selected models were submitted to the outlier detection test, which indicated the presence of discrepant observations with studentized residual values higher than -2 and 2. However, these have a small contribution to the estimates due to the low leverage values. Moreover, the exclusion of these observations resulted in negligible improvement in RMSE\% and adj- $\mathrm{R}^{2}$. Therefore, we decided to keep these observations in the database, as they represent real values of the sampled populations. The selected models presented satisfactory statistical results through leaveone-out cross-validation (Tab. S2 in Supplementary material), such as high efficiency and reduced prediction errors, ensuring stability in the estimates.

Generic models presented similar fitting results to the specific models for forest types and timber species (Tab. 3, Tab. 4). The fitting and accuracy statistics were similar, even with using these models for other datasets (Tab. 5), in which the variation in efficiency (adj-R ${ }^{2}$ ) and accuracy (RMSE\%) was minimal. The hypothesis tests $\left(X^{2}, V\right.$, and $\mathrm{H}$ ) did not reject the null hypotheses ( $p>0.01$ ), showing evidence of significant similarity between generic and specific predictions. Similarly, Willmott's Agreement Index ( $\mathrm{dw}$ ) showed high agreement among predictions. Therefore, generic and specific models resulted in similar estimates ( $p>0.01)$. Finally, hypothesis I was accepted and hypothesis II was rejected, since nonsignificant loss of accuracy could be evidenced using generic models.

\section{Discussion}

The volume models of this study are new for the Brazilian Atlantic Forest. Volume 
prediction models for forest types and species on a regional scale were only developed for some Brazilian States (Scolforo et al. 2008, Vibrans et al. 2015). Additionally, total volume models that consider crown volume are rare for Atlantic Forests (Oliveira et al. 2018), in which this study is also a pioneer. These models can provide estimates of forest growth in the National Forest Inventory (Gschwantner et al. 2019) to support the management of secondary forests (Oliveira et al. 2018, Fantini et al. 2019).

Environmental heterogeneity may explain the variation in allometric relationships between forest types (Fig. 2). The wide environmental variability present in the Southeast of Brazil provides the formation of several vegetation types characterized by typical flora (Scarano 2002, Nettesheim et al. 2010). These environmental conditions determine the diversity and structural complexity among plant communities (Scarano 2002). In this sense, the similarities that were observed for allometric relationships among forest types (Fig. 2) are related to the affinity of their species composition and structure (Vibrans et al. 2015). Even with evident environmental variation, the Ombrophilous (DOF) and Seasonal (SSF) forests have greater floristic similarity to each other than to the other Atlantic Forest formations (Oliveira-Filho \& Fontes 2000). In the study area, the similarity between these forest types is corroborated by the phytogeographic patterns found for the flora (Nettesheim et al. 2010).

Environmental restrictions explain the lowest volume and difference of allometric relationship in the Restinga forests (RES Fig. 2). This forest type covers the coastal sandy plains, where shrub vegetation predominates (Scarano 2002). Such soil conditions (low fertility and frequent flooding) provide more restrictive environments for establishing tree species (Assis et al. 2011) that restrict the tree size and density (Magnago et al. 2013). Thus, this forest type has an evident floristic and structural difference in relation to the others, marked by the presence of typical and smaller species adapted to edaphic characteristics (Assis et al. 2011, Magnago et al. 2013).

The Schumacher-Hall's model (4) selected as the most appropriate for estimating stem volume of forest types (Tab. 3) is widely used to predict tree volume in tropical and subtropical regions (Akindele \& LeMay 2006, Vibrans et al. 2015). Spurr's model (3), selected in this study for total volume, was also cited as the most accurate for tree total volume predictions in Tanzania, considering local specific models for four geographic regions (Mauya et al. 2014).

The better prediction of stem volume in comparision to total volume (Tab. 3) may be related to the sample size (Segura \& Kanninen 2005). We highlight that the optimal sampling for all databases was achieved (Tab. 1). On the other hand, the high variability of tropical tree crown pat- terns can affect the fit of total volume models (Mauya et al. 2014). In general, the stem volume is more homogeneous than total volume, and its allometric attributes are more easily described by tree diameter and height (Oliveira et al. 2018).

In this study, tree crown represented, on average, $30.1 \%$ of the total volume, varying according to forest type (DOF $=30.7 \%$; RES $=34.2 \%$; SSF $=28.0 \%$ ). Crown volume in subtropical regions of the Atlantic Forest can represent up to $34.5 \%$ of total tree volume (Oliveira et al. 2018). However, most allometric models developed in tropical forests only estimate the stem volume and do not consider the volume of thick branches (Segura \& Kanninen 2005). Crown volume is an important component of timber stocks in natural forests, so it should not be ignored in management systems (Oliveira et al. 2018) or in forest biomass and carbon predictions (Nogueira et al. 2008).

Inserting height as a predictor variable increased the accuracy of the stem volume prediction by up to $10 \%$ and the total volume by $7 \%$ (Tab. 3). The use of height to estimate volume and biomass in tropical forests is controversial (Hunter et al. 2013), especially due to measurement difficulties in dense forests (Segura \& Kanninen 2005, Oliveira et al. 2018). However, height as a predictor of tree biomass, for example, significantly increases the accuracy of estimates in tropical forests (Chave et al. 2005, Feldpausch et al. 2012, Hunter et al. 2013). Tree height measurement can be improved by training the forest operators (Kitahara et al. 2010) and with the use of LIDAR sensor fine-scale data (Clark et al. 2004).

At regional scales, where environmental heterogeneity may increase the variability of allometric relationships (Mauya et al. 2014, Vibrans et al. 2015), using tree height is recommended for predictions (Feldpausch et al. 2012). Height use is emphasized in situations where there is a wide range of heights for the same diameter range (Mensah et al. 2017), as in natural rainforests. Tree height is still recommended for predicting the volume of large trees since it complements the effect of diameter in volume models (Rolim et al. 2006, Mauya et al. 2014). As height measurements are time-consuming, it is recommended that sampling be optimized to produce an adequate local allometric relationship (Hunter et al. 2013) and improve volume estimates in dense forests.

We highlight that Kopezky-Gehrhardt's single-predictor model 1 provides estimates with valid confidence intervals and can be used for volume predictions (Tab. 3). Due to measurement difficulties and the increased cost of data collection, the use of single-predictor models with only diameter is an alternative for management operations in Brazilian dense forests ( $\mathrm{Gi}$ menez et al. 2017, Oliveira et al. 2018). Diameter is a variable easily measured in forest inventories (Segura \& Kanninen 2005) that expand the applicability of single-pre- dictor models.

Similar to the models fitted for forest types, two-predictor models presented a superior performance for timber species (Tab. 4). For A. graveolens, the accuracy gain in the models was more evident with height inclusion due to the wide variation in height for the same diameter. Height explains the variation of tree biomass for a given value of diameter (Mensah et al. 2017), increasing the predictive potential of models. The largest errors with specific models were obtained for $P$. contorta. This species produces the biggest trees in the Ombrophilous Forest in the Rio de Janeiro state (Cysneiros et al. 2015). Morphological variability is more evident in large trees (Alves \& Santos 2002), for which the highest errors in volume predictions are justified (Mauya et al. 2014).

Deviation from normality observed at the extreme of residual distributions (Fig. 4, Fig. 5) may indicate population mixing or the existence of subpopulations in the generic and specific databases. Local climate and soil conditions affect allometric relationships in tropical forests (Mauya et al. 2014), conditioning the existence of different subpopulations within the same forest type. The effect of altitude on height/diameter relationships in the Atlantic Forest is known (Scaranello et al. 2012). This evidence emphasizes the influence of the local environment in tree allometric relationships and explains the presence of subpopulations on databases.

The assessment of volume models conducted by Vibrans et al. (2015) in the Atlantic Forest indicated the need for specific models for each forest type. Their result was different from that of this study, in which generic models provided accurate estimates with valid confidence intervals (Tab. 3, Tab. 4, Tab. 5). The recommendation of specific models for forest types is related to the floristic and structural differences between these forests (Vibrans et al. 2015). Even though there are floristic differences in the forests of the Brazilian Southeast (Nettesheim et al. 2010), generic and specific volume models did not present significant differences for the estimates (Tab. 5). The larger number of species in the generic models increases data variability and reduces the accuracy of estimates in relation to specific models (Mauya et al. 2014, Vibrans et al. 2015). Therefore, in this study, the accuracy and efficiency of generic models were not compromised. Thus, these models allow for improvement in the generalizability of the estimates for larger areas.

Generic volume models provide wider uses (Vibrans et al. 2015), as they cover a range of geographical and biophysical conditions (Mauya et al. 2014). Moreover, it is evident that additional effort to collect data for species-specific models does not lead to a relevant gain in accuracy in comparison to generic models (Oliveira et al. 2018). In the context of NFIs, fieldwork 
should focus on allometric models that reduce population variability through larger and consistent samples (McRoberts \& Westfall 2016), such as the selected generic models. Therefore, the generic models efficiently described the variability of tree volume between forest types. These models can be used for tree volume predictions in the Atlantic Forest in Rio de Janeiro state, while specific models are recommended for more detailed local estimates. Additionally, the selected specific models can be applied for forest types present in other regions of Atlantic Forest with lack of local models.

\section{Conclusions}

Two main conclusions were obtained in this study: (1) generic models allowed estimates with acceptable confidence intervals and can be used in all forest types in the studied area; and (2) contrary to expectations, estimates by generic models did not show a decrease in accuracy in relationship to the specific models by forest type and species.

\section{Acknowledgements}

VCC collected data, conducted data analyses and wrote the manuscript; TDG participated on data collection and conducted data analyses; ALP conducted data analyses and contributed to the text; TAM participated on data collection and graphic analyses; DCC, TBSF, HBA, SAM supervised data analyses and contributed to the text. The authors thank all members of the National Forest Inventory of Rio de Janeiro State and the Brazilian Council for Scientific and Technological Development (CNPq) for granting the scholarship to the first author (Process: 140594/2017-5). This study was sponsored by the Fundação Flora de Apoio a Botânica, through a partnership with the State Secretariat of the Environment (SEA$\mathrm{RJ}$ ) and State Institute of Environment (INEA-RJ), by Agreement no. 01/2017, for development and implementation of the Carbon Climate Rio Program. The authors grateful to anonymous reviewers for the valuable review and comments.

\section{References}

Akindele SO, LeMay VM (2006). Development of tree volume equations for common timber species in the tropical rain forest area of Nigeria. Forest Ecology and Management 226: 4148. - doi: 10.1016/j.foreco.2006.01.022

Alvares CA, Stape JL, Sentelhas PC, De Moraes Gonçalves JL, Sparovek G (2013). Köppen's climate classification map for Brazil. Meteorologische Zeitschrift 22: 711-728. - doi: 10.1127/09412948/2013/0507

Alves LF, Santos FAM (2002). Tree allometry and crown shape of four tree species in Atlantic rain forest, south-east Brazil. Journal of Tropical Ecology 18: 245-26o. - doi: 10.1017/S0266467 40200216X

Assis MA, Prata EMB, Pedroni F, Sanchez $M$, Eisenlohr PV, Martins FR, Santos FAM, Tamashiro JY, Alves LF, Vieira SA, Piccolo MDC, Mar- tins SC, Camargo PB, Carmo JB, Simões E, Martinelli LA, Joly CA (2011). Florestas de restinga e de terras baixas na planície costeira do sudeste do Brasil: vegetação e heterogeneidade ambiental [Restinga and Lowland forests in coastal plain of southeastern Brazil: vegetation and environmental heterogeneity]. Biota Neotropica 11: 103-121. [in Portuguese] - doi: 10.1590/S167606032011000200012

Avery TE, Burkhart HE (2015). Forest measurements ( $5^{\text {th }}$ edn). Waveland Press Inc., Long Grove, IL, USA, pp. 456. [online] URL: http:// books.google.com/books?id=IWx1CQAAQBAJ Bennett ND, Croke BFW, Guariso G, Guillaume JHA, Hamilton SH, Jakeman AJ, Marsili-Libelli S, Newham LTH, Norton JP, Perrin C, Pierce SA, Robson B, Seppelt R, Voinov AA, Fath BD, Andreassian $V$ (2013). Characterising performance of environmental models. Environmental Modelling and Software 40: 1-20. - doi: 10.1016/j.env soft.2012.09.011

Bergamin R, Müller S, Mello R (2012). Indicator species and floristic patterns in different forest formations in southern Atlantic rainforests of Brazil. Community Ecology 13: 162-170. - doi: 10.1556/comec.13.2012.2.5

Boyle B, Hopkins N, Lu Z, Raygoza Garay JA, Mozzherin D, Rees T, Matasci N, Narro ML, Piel WH, Mckay SJ, Lowry S, Freeland C, Peet RK, Enquist BJ (2013). The taxonomic name resolution service: an online tool for automated standardization of plant names. BMC Bioinformatics 14: e16. - doi: 10.1186/1471-2105-14-16

Breusch TS, Pagan AR (1979). A simple test for heteroscedasticity and random coefficient variation. Econometrica 47: 1287-1294. - doi: 10.2307 /1911963

Chave J, Andalo C, Brown S, Cairns MA, Chambers JQ, Eamus D, Fölster H, Fromard F, Higuchi $\mathrm{N}$, Kira T, Lescure J-P, Nelson BW, Ogawa $\mathrm{H}$, Puig H, Riéra B, Yamakura T (2005). Tree allometry and improved estimation of carbon stocks and balance in tropical forests. Oecologia 145: 87-99. - doi: 10.1007/s00442-005-0100-x

Clark ML, Clark DB, Roberts DA (2004). Smallfootprint lidar estimation of sub-canopy elevation and tree height in a tropical rain forest landscape. Remote Sensing of Environment 91: 68-89. - doi: 10.1016/j.rse.2004.02.008

Cysneiros VC, Mendonça-Junior JDO, Gaui TD, Braz DM (2015). Diversity, community structure and conservation status of an Atlantic Forest fragment in Rio de Janeiro State, Brazil. Biota Neotropica 15: e20140132. - doi: 10.1590/1676060320150132

Fantini AC, Schuch C, Siminski A, Siddique I (2019). Small-scale management of secondary forests in the Brazilian Atlantic Forest. Floresta e Ambiente 26: e20170690. - doi: 10.1590/21798087.069017

Feldpausch TR, Lloyd J, Lewis SL, Brienen RJW, Gloor M, Monteagudo Mendoza A, Lopez-Gonzalez G, Banin L, Abu Salim K, Affum-Baffoe K, Alexiades M, Almeida S, Amaral I, Andrade A, Aragão LEOC, Araujo Murakami A, Arets EJMM, Arroyo L, Aymard CGA, Baker TR, Bánki OS, Berry NJ, Cardozo N, Chave J, Comiskey JA, Alvarez $E$, Oliveira A, Di Fiore A, Djagbletey $G$, Domingues TF, Erwin TL, Fearnside PM, França $M B$, Freitas MA, Higuchi $N$, Honorio $C$, lida $Y$, Jiménez E, Kassim AR, Killeen TJ, Laurance WF,
Lovett JC, Malhi Y, Marimon BS, Marimon-Junior BH, Lenza E, Marshall AR, Mendoza C, Metcalfe DJ, Mitchard ETA, Neill DA, Nelson BW, Nilus R, Nogueira EM, Parada A, Peh KSH, Pena Cruz A, Peñuela MC, Pitman NCA, Prieto A, Quesada CA, Ramírez F, Ramírez-Angulo $\mathrm{H}$, Reitsma JM, Rudas A, Saiz G, Salomão RP, Schwarz M, Silva N, Silva-Espejo JE, Silveira $M$, Sonké $B$, Stropp J, Taedoumg HE, Tan S, Ter Steege H, Terborgh J, Torello-Raventos M, Van Der Heijden GMF, Vásquez R, Vilanova $E$, Vos VA, White L, Willcock S, Woell H, Phillips OL (2012). Tree height integrated into pantropical forest biomass estimates. Biogeosciences 9: 3381-3403. doi: 10.5194/bg-9-3381-2012

Fox J, Weisberg S (2019). An R companion to applied regression ( $3^{\text {rd }}$ edn). SAGE, Los Angeles, USA, pp. 577.

Gimenez BO, Santos LT, Gebara J, Celes CHS, Durgante FM, Lima AJN, Santos J, Higuchi N (2017). Tree climbing techniques and volume equations for Eschweilera (Matá-Matá), a hyperdominant genus in the Amazon Forest. Forests 8: 154. - doi: 10.3390/f8050154

Gross J, Ligges U (2015). R package "nortest": tests for normality (version 1.0-4). Web site. [online] URL: http://CRAN.R-project.org/packa ge=nortest

Gschwantner T, Alberdi I, Balázs A, Bauwens S, Bender S, Borota D, Bosela M, Bouriaud O, Cañellas I, Donis J, Freudenschub A, Hervé JC, Hladnik D, Jansons J, Kolozs L, Korhonen KT, Kucera M, Kulbokas G, Kuliesis A, Lanz A, Lejeune $P$, Lind T, Marin G, Morneau F, Nagy D, Norden-Larsen T, Nunes L, Pantic D, Paulo JA, Pikula T, Redmond J, Rego FC, Riedel T, Saint-André L, Seben V, Sims A, Skudnik M, Solti G, Tomter SM, Twomey M, Westerlund B (2019). Harmonisation of stem volume estimates in European National Forest Inventories. Annals of Forest Science 76: 24. - doi: 10.1007/s13595-0190800-8

Hunter MO, Keller M, Victoria D, Morton DC (2013). Tree height and tropical forest biomass estimation. Biogeosciences 10: 8385-8399. - doi: 10.5194/bg-10-8385-2013

Jara MC, Henry M, Réjou-Méchain $M$, Wayson $C$, Zapata-Cuartas M, Piotto D, Guier FA, Lombis HC, López EC, Lara RC, Rojas KC, Pasquel JDA, Montoya AD, Vega JF, Galo AJ, López OR, Marklund LG, Fuentes JMM, Milla F, Chaidez JJN, Malavassi EO, Pérez J, Zea CR, García LR, Pons RR, Saint-André L, Sanquetta C, Scott C, Westfall J (2015). Guidelines for documenting and reporting tree allometric equations. Annals of Forest Science 72: 763-768. - doi: 10.1007/s135 95-014-0415-z

Kitahara F, Mizoue N, Yoshida S (2010). Effects of training for inexperienced surveyors on data quality of tree diameter and height measurements. Silva Fennica 44: 657-667. - doi: 10.14214/ sf.133

Kuhn M, Wing J, Weston S, Williams A, Keefer C, Engelhardt A, Cooper T, Mayer Z (2018). R package "caret": classification and regression training (version v6.0.77). Web site. [online] URL: http://github.com/topepo/caret/

Laman TG (1995). Safety recommendations for climbing rain forest trees with "single rope technique”. Biotropica 27: 406-409. - doi: 10.23 $07 / 2388928$ 
Magnago LFS, Martins SV, Schaefer CEGR, Neri AV (2013). Structure and diversity of restingas along a flood gradient in southeastern Brazil. Acta Botanica Brasilica 27: 801-809. - doi: 10.159 o/S0102-33062013000400020

Mauya EW, Mugasha WA, Zahabu E, Bollandsås OM, Eid T (2014). Models for estimation of tree volume in the Miombo woodlands of Tanzania. Southern Forests 76: 209-219. - doi: 10.2989/20 702620.2014.957594

McRoberts RE, Tomppo EO, Schadauer K, Ståhl $G$ (2012). Harmonizing national forest inventories. Forest Science 58: 189-190. - doi: 10.5849/ forsci.12-042

McRoberts RE, Westfall JA (2016). Propagating uncertainty through individual tree volume model predictions to large-area volume estimates. Annals of Forest Science 73: 625-633. doi: 10.1007/s13595-015-0473-x

Mensah S, Veldtman R, Seifert T (2017). Allometric models for height and aboveground biomass of dominant tree species in South African Mistbelt forests. Southern Forests 79: 19-30. doi: 10.2989/20702620.2016.1225187

Nascimento LB, Das Neves Brandes AF, Valente FDW, Tamaio N (2017). Anatomical identification of commercialized wood in the state of Rio de Janeiro, Brazil. Brazilian Journal of Botany 40: 291-329. - doi: 10.1007/s40415-016-0324-5

Nettesheim FC, De Menezes LFT, De Carvalho DC, Conde MMS, De Araujo DSD (2010). Influence of environmental variation on Atlantic Forest tree-shrub-layer phytogeography in southeast Brazil. Acta Botanica Brasilica 24: 369-377. - doi: 10.1590/S0102-330620100002000 07

Nogueira EM, Fearnside PM, Nelson BW, Barbosa RI, Keizer EWH (2008). Estimates of forest biomass in the Brazilian Amazon: new allometric equations and adjustments to biomass from wood-volume inventories. Forest Ecology and Management 256: 1853-1867. - doi: 10.1016/j.for eco.2008.07.022

Oliveira LZ, Klitzke AR, Fantini AC, Uller HF, Correia J, Vibrans AC (2018). Robust volumetric models for supporting the management of secondary forest stands in the Southern Brazilian Atlantic Forest. Anais da Academia Brasileira de Ciências 90: 3729-3744. - doi: 10.1590/0001-3765 201820180111

Oliveira-Filho AT, Fontes MAL (2000). Patterns of floristic differentiation among Atlantic Forests in Southeastern Brazil and the influence of climate. Biotropica 32: 793-810. - doi: 10.1111/j.17447429.2000.tboo619.x

Razali NM, Wah YB (2011). Power comparisons of Shapiro-Wilk, Kolmogorov Smirnov, Lilliefors and Anderson-Darling tests. Journal of Statistical Modeling and Analytics 2: 21-33. [online] URL: http://www.researchgate.net/publication/ 267205556

Ribeiro MC, Metzger JP, Martensen AC, Ponzoni FJ, Hirota MM (2009). The Brazilian Atlantic Forest: how much is left, and how is the remaining forest distributed? Implications for conservation. Biological Conservation 142: 11411153. - doi: 10.1016/j.biocon.2009.02.021

Ribeiro FCA, Lauria DDC, Silva JIR, Lima ESA, Amaral Sobrinho NMBD, Pérez DV (2018). Baseline and quality reference values for natural radionuclides in soils of Rio de Janeiro State, Brazil. Revista Brasileira de Ciência do Solo 42: e0170146. - doi: 10.1590/18069657rbcs20170146 Rolim SG, Couto HTZD, De Jesus RM, França JT (2006). Modelos volumétricos para a Floresta Nacional do Tapirapé-Aquirí, Serra dos CarajásPA [Volumetric models for Tapirapé-Aquirí National Forest, Pará, Brazil]. Acta Amazonica 36: 107-114. [in Portuguese] - doi: 10.1590/Soo4459672006000100013

Scaranello MADS, Alves LF, Vieira SA, Camargo PBD, Joly CA, Martinelli LA (2012). Height-diameter relationships of tropical Atlantic moist forest trees in southeastern Brazil. Scientia Agricola 69: 26-37. - doi: 10.1590/S0103-90162012000 100005

Scarano FR (2002). Structure, function and floristic relationships of plant communities in stressful habitats marginal to the Brazilian Atlantic rainforest. Annals of Botany 90: 517-524. - doi: 10.1093/aob/mcf189

Scolforo JRS, Oliveira AD, Acerbi-Júnior FW (2008). Equações de volume, peso de matéria seca e carbono para diferentes fisionomias da flora nativa [Volume, dry matter weight and carbon equations for different physiognomies of native flora]. EDUFLA, Lavras, Brazil, pp. 216. [in Portuguese]

Segura M, Kanninen M (2005). Allometric models for tree volume and total aboveground biomass in a tropical humid forest in Costa Rica. 1: Allometric models of volume and biomass. Biotropica 37: 2-8. - doi: 10.1111/j.1744-7429.2005.02 027. $\mathrm{x}$

Serviço Florestal Brasileiro (2018). Inventário florestal nacional: Rio de Janeiro - principais resultados [Brazilian National Forest Inventory: Rio de Janeiro State - main results]. MMA, Brasília, Brazil, pp.116. [in Portuguese]

Sileshi GW (2014). A critical review of forest biomass estimation models, common mistakes and corrective measures. Forest Ecology and Management 329: 237-254. - doi: 10.1016/j.for eco.2014.06.026
Sobral BS, Oliveira-Júnior JF, Gois G, Terassi PMDB, Muniz-Júnior JGR (2018). Spatial temporal and interanual rainfall variability in the state of Rio de Janeiro. Revista Brasileira de Climatologia 22: 281-308. - doi: 10.5380/abclima.v22io. 55592

Stoval AEL, Anderson-Teixeira KJ, Shugart $\mathrm{HH}$ (2018). Assessing terrestrial laser scanning for developing non-destructive biomass allometry. Forest Ecology and Management 427: 217-229. doi: 10.1016/j.foreco.2018.06.004

The Angiosperm Phylogeny Group (2016). An update of the Angiosperm Phylogeny Group classification for the orders and families of flowering plants: APG IV. Botanical Journal of the Linnean Society 181: 1-20. - doi: 10.1111/boj.12385

Vibrans AC, Moser P, Oliveira LZ, Maçaneiro JP (2015). Generic and specific stem volume models for three subtropical forest types in southern Brazil. Annals of Forest Science 72: 865-874. - doi: 10.1007/s13595-015-0481-x

Vidal C, Alberdi I, Redmond J, Vestman M, Lanz A, Schadauer K (2016). The role of European national forest inventories for international forestry reporting. Annals of Forest Science 73: 793-806. - doi: 10.1007/s13595-016-0545-6 Willmott CJ (1981). On the validation of models. Physical Geography 2: 184-194. - doi: 10.1080/02 723646.1981.10642213

Zambrano-Bigiarini M (2017). R package "hydroGOF": goodness-of-fit functions for comparison of simulated and observed hydrological time series. Web site. [online] URL: http://github. com/hzambran/hydroGOF

\section{Supplementary Material}

Tab. S1 - Tree species sampled by Atlantic Forest types to fit stem and total volume equations.

Tab. S2 - Cross-validation statistics of the selected models for stem and total volume predictions in Atlantic Forest.

Fig. S1 - Non-destructive climbing method for tree measurements.

Fig. S2 - Tree volume-diameter relationships for main timber species in the Brazilian Atlantic Forest, showing Apuleia leiocarpa (Apu), Astronium graveolens (Ast), Miconia cinnamomifolia (Mic), and Pseudopiptadenia contorta (Pse).

Link: Cysneiros_3495@supplo01.pdf 